Journal of Applied Pharmaceutical Science Vol. 5 (06), pp. 001-007, June, 2015

Available online at http://www.japsonline.com

DOI: $10.7324 / \mathrm{JAPS} .2015 .50601$

ISSN 2231-3354 (cc) BY-NC-SA

\title{
Synthesis and trypanocidal activity of salicylhydrazones and p-tosylhydrazones of S-(+)-carvoneand arylketones on African trypanosomiasis
}

\author{
Bienvenu GLINMA ${ }^{1.2 .4}$, Fernand A. GBAGUIDI ${ }^{1.23^{*}}$, Urbain C. KASSEHIN ${ }^{3}$, Salomé D.S. KPOVIESSI ${ }^{1}$, Alban \\ HOUNGBEME $^{2}$, Horrhus D. HOUNGUE ${ }^{3}$, Georges C. ACCROMBESSI ${ }^{1}$ and Jacques H. POUPAERT ${ }^{3}$ \\ ${ }^{1}$ Laboratoire de Chimie Organique Physique et de Synthèse, Département de Chimie, Faculté des Sciences et Techniques, Université d'Abomey-Calavi, 01 \\ BP 4521 Cotonou, République Bénin. ${ }^{2}$ Laboratoire de Pharmacognosie/Institut de Recherche et d'Expérimentation en Médecine et Pharmacopée \\ Traditionnelles (IREMPT) / Centre Béninois de la Recherche Scientifique et Technique (CBRST)/ UAC, 01 BP 06 Oganla Porto-Novo. ${ }^{3}$ Laboratoire de \\ Chimie Pharmaceutique Organique, Ecole de Pharmacie, Faculté des Sciences de la Santé, Université d'Abomey-Calavi, Campus du Champ de Foire, 01 BP \\ 188, Cotonou, Bénin. ${ }^{4}$ Louvain Drug Research Institute (LDRI), School of Pharmacy, Université Catholique de Louvain, B1 7203 Avenue Emmanuel \\ Mounier 72, B-1200 Brussels, Belgique.
}

\section{ARTICLE INFO \\ Article history: \\ Received on: 06/03/2015 \\ Revised on: 09/04/2015 \\ Accepted on: 22/04/2015 \\ Available online: 27/06/2015}

\section{Key words:}

Salicylhydrazones, p-tosylhydrazones, trypanocidal activity, selectivity index.

\begin{abstract}
Hydrazones are nowadays considered to be good candidates for various pharmaceutical applications. Here, we have synthesized two series of hydrazones: salicylhydrazones (GS1-4) and $p$-tosylhydrazones (GT1-4) from S$(+)$-carvone and three aryketones with good yields $(57-91 \%)$. Molecules were characterized by elemental analyses; TLC, NMR ${ }^{1} \mathrm{H}$, NMR ${ }^{13} \mathrm{C}$ and MS. Submitted, in vitro, to their antiparasitic testing on Trypanosoma brucei brucei, and toxicity on Artemia salina Leach, all compounds except GT2 showed significant antitrypanosomal activity $\mathrm{IC}_{50}$ ranging from 1 to 34 micromolar $(\mu \mathrm{M})$. Among them, 2-acetynaphthalene salicylhydrazone GS4 $\left(\mathrm{IC}_{50}=1.97 \pm 0.42 \mu \mathrm{M}\right)$ and 7-methoxy-1-tetralone $p$-tosylhydrazone GT3 $\left(\mathrm{IC}_{50}=7.98 \pm\right.$ $1.65 \mu \mathrm{M}$ ) exhibited good trypanocidal activity and the other are moderates on parasite; when the compounds GS1, GT3 and GT4 presented toxic activity on larvae. In agreement to their selectivity index, which is greater than 1 (SI > 1), products turn out quite selective on the parasite: a series of salicylhydrazones revealed more selective (SI $\geq 11)$, especially GS4 $(\mathrm{SI}=157)$ than the series of $p$-tosylhydrazones showed $1 \leq \mathrm{SI} \leq 22$. The synthesized compounds clearly displayed significant selective pharmaceutical activities on the parasite tested. Compounds developing could open promising route to news drug-candidates.
\end{abstract}

\section{INTRODUCTION}

Hydrazides and hydrazones are nowadays an important class of biologically active compounds (Ali et al., 2012; Narasimhan et al., 2010). They exhibit a wide range of interesting pharmaceutical derivatives and are also important intermediates in organic synthesis (Rollas et al., 2007). In addition, these compounds have shown anti-cancer properties (Wandakhan et al., 2013; El-Sabbagh and Rady, 2009; Zhang et al., 2004), anti-HIV (Vicini et al., 2009) and are potential inhibitors for many enzymes (Xu et al., 2008; Hassanien et al., 2008; Singh et Kumar, 2006), DNA synthesis and cell growth

* Corresponding Author

Email:ahokannou@yahoo.fr
(Sreeja et al., 2004) and therefore they acquired an important place in medicinal chemistry.

Some hydrazide-hydrazones derivatives have been commercialized: the nifurtimox is used for the treatment of Chagas' disease (Melnyk et al., 2006) and nifuroxazide (D) as intestinal antiseptic (Küçükgüzel et al., 2003). Hydrazones can act as polydentate ligands, depending on the nature of the substituent attached to the hydrazone unit. We also note that their complexing properties give them the opportunity to be interesting candidates for drugs based on transition metals.

In general, the ligands act synergistically with metals for their biological activity (Badiger et al., 2012). Hydrazideshydrazones are also used as analytical reagents, a polymer coating of ink, pigments and fluorescent materials (El-Tabl et al., 2008). 
These molecules are known possessing several interesting biological properties, among others, antibacterial (Özkay et al., 2010; Bedia et al., 2006), anticonvulsant (Kaushik et al., 2010), antitrypanosomal (Troeberg et al., 2000), anti-fungal (Cui et al., 2011, Loncle et al., 2004), antipyretic (Cocco et al., 2006), malaria (Xia et al., 2008).

Based on higher bio-activity, the biological importance of the hydrazone group and its derivatives, it appears important to design, synthesize new derivatives with the pharmacophore hydrazone group and evaluate their pharmacological activities.

In this study we have synthesized two derivatives of hydrazones: the salicylhydrazones (series GS) and the $p$ tosylhydrazones (series GT) respectively with S-(+)-carvone (GS1, GT1), 4'-methylacetophenone (GS2, GT2), 7-methoxy-1-tetralone (GS3, GT3) and 2-acetylnaphthalene (GS4, GT4) and then evaluate their parasitic activity on Trypanosoma brucei brucei. The selectivity of each compound was also determined.

\section{MATERIALS AND METHODS Equipment}

All synthesized compounds were characterized by Nuclear Magnetic Resonance spectra using Bruker Avance 400 UltraSheild with dimethylsufoxide (DMSO) $-\mathrm{d}_{6}$ or chloroform $\mathrm{CDCl}_{3}$ and then Mass Spectrophotometer spectra obtained using the method of Atmospheric-pressure chemical ionization and mass is given in $\mathrm{m} / \mathrm{z}$ of $\left[\mathrm{MH}^{+}\right]$.

The frequencies for ${ }^{1} \mathrm{H}$ and ${ }^{13} \mathrm{C}$ are 400.130 and 100.612 $\mathrm{MHz}$ respectively. Chemical shifts are given in parts per million (ppm) relative to tetramethylsilane as internal standard. Multiplicity was designated as singlet (s), doublet dedouble (dd) triplet (t), quintuplet (qi) and multiplet (m). Melting points (m.p.) were determined on a fusionometer of the type electrothermal $1 \mathrm{~A}$ 9000 and were not corrected.

\section{Reagents}

All reagents were obtained from chemical societies: Sigma-Aldrich, Acros Organic, Janssen Chimica, Prolabo and Riedel-de Haen. Substrates, reagents, catalysts and solvents were used directly for syntheses without any further purification. There are: S-(+)-carvone, 4'-methylacetophenone, 7-methoxy-1-tetralone, 2-acetylnaphthalene; glacial acetic acid (AAG), Technical ethanol $(\mathrm{EtOH})$, tetrahydrofuran (THF); salicylhydrazine and the paratoluenesulfonylhydrazide ( $p$-tolylhydrazide) is prepared from the hydrazine monohydrate with the $p$-toluenesulfonyl chloride following the method described in the previous literature (Goldman et al., 1960).

\section{Chemistry}

\section{General methods of synthesis}

$p$-tolylhydrazide ( $p$-toluenesolfonylhydrazide)

Into a $1 \mathrm{~L}$ round-bottomed three-necked flask fitted with a thermometer, a mechanical stirrer, and a dropping funnel are placed $200 \mathrm{~g}$ (1.05 moles) of $p$-toluenesulfonyl chloride and 350 $\mathrm{mL}$ of tetrahydrofuran. The stirred mixture is cooled in an ice bath to $10-15^{\circ} \mathrm{C}$; then a solution of hydrazine in water $(135 \mathrm{~mL}$ of $85 \%$ hydrazine hydrate, 2.22 moles) is added at such a rate that the temperature is maintained between $10^{\circ}$ and $20^{\circ} \mathrm{C}$. Stirring is continued for 15 minutes after the addition is complete. The reaction mixture is transferred to a separatory funnel. The lower layer is drawn off, and discarded. The upper tetrahydrofuran layer is filtered by suction through a bed of Celite to remove suspended particles and foreign matter (if any). The Celite is washed with a little tetrahydrofurane to remove any absorbed tosylhydrazide. The clear, colorless filtrates are stirred vigorously during the slow addition of two volumes of distilled water. $p$ toluenesulfonylhydrazide separates as fluffy white crystalline needles. The product is filtered through a Büchner funnel; washed several times with distilled water, and air-dried.

\section{p-tosylhydrazones}

In a $100 \mathrm{~mL}$ flask, we prepare a solution of 0.01 mole of ketone in $10-40 \mathrm{~mL}$ of ethanol and $2 \mathrm{~mL}$ of glacial acetic acid (GAA) and then we add gradually a solution of $p$-tosylhydrazide $(1.76 \mathrm{~g})$ dissolved in $10 \mathrm{~mL}$ ethanol. The mixture is maintained at reflux for 2 hours and the reaction is followed by Thin Layer Chromatography TLC (Hex / AcOEt: 8/2 or 7/3). The crystals formed are filtered, washed with distilled water and dried before being recrystallized with ethanol.

\section{Salicylhydrazones}

We prepare in a $100 \mathrm{~mL}$ flask a salicylhydrazine solution ( $1.52 \mathrm{~g}$ in $10 \mathrm{~mL}$ of ethanol) that we gradually add to a solution of ketone $(0.01$ mole) dissolved in $10-40 \mathrm{ml}$ of ethanol and $2 \mathrm{~mL}$ of glacial acetic acid. The mixture is brought to reflux for 2 hours and the reaction is followed by TLC (Hex / AcOEt: 8/2 or 7/3). After cooling, the precipitate is filtered off, washed with distilled water and dried and then is recrystallized from technical ethanol.

The reactions are followed in Thin Layer chromatography (TLC), the product is dissolved in chloroform and the eluent is composed of a mixture of hexane / ethyl acetate (Hex / EtOAc v / v: 7/3; 8/2).

All compounds after synthesis have been submitted to the in vitro anti-trypanosomal testing activity on the bloodstream form of the strain 427 of Trypanosoma brucei brucei and were evaluated for their in vitro cytotoxicity on Artemia salina Leach following standard biological methods.

\section{Pharmacology \\ Anti-trypanosomal test}

The assessment is performed on the bloodstream form of the strain 427 of $T$. b. brucei by the «LILIT Alamar Blue ${ }^{\mathrm{TM}}$ » method (Baltz et al., 1985 ; Räz et al., 1997). The stock solutions of each hydrazone have been prepared from an initial concentration of $10 \mathrm{mg} / \mathrm{mL}$ in dimethylsufoxide (DMSO). The trypanosomes are grown in a medium containing $10 \%$ of heatinactivated fetal calf serum and bloodstream form supporting factor. The trypanosome suspensions were adjusted to $5 \times 10^{4}$ tryp/mL. In each well, $50 \mu \mathrm{L}$ of different dilutions of the stock 
solution were added to $50 \mu \mathrm{L}$ of suspension of trypanosomes. The plates were then incubated at $37^{\circ} \mathrm{C}$ for 72 hours in an atmosphere with $5 \% \mathrm{CO}_{2} .10 \mu \mathrm{L}$ of dye "Alamar Blue ${ }^{\mathrm{TM}}$ " is added to each well and then incubated for 4 hours. The dye "Alamar Blue ${ }^{\mathrm{TM}}$ is a reagent for detecting enzymatic activity. The wells in which the concentration of compound is insufficient to inhibit the proliferation of trypanosomes are stained. The half-inhibitory concentration is the concentration of unstained wells in which there is the lowest amount of hydrazones. The plate reading is made in comparison with control wells on a fluorescence plate reader using an excitation wavelength of $530 \mathrm{~nm}$ and an emission wavelength $590 \mathrm{~nm}$. We carried out the test in triplicate for each compound. All data were expressed as means \pm standard deviation of triplicate measurements.

\section{Cytotoxicity screen}

The cytotoxicity test was performed on larvae of brine shrimp (Artemia salina Leach) by the method of Sleet and Brendel (1983). A. salina eggs were incubated in seawater until hatching of young larvae (48 hours). Then, series of solutions of test compound at varying concentrations were prepared in $\mathrm{DMSO} / \mathrm{seawater}$. A defined number of larvae were introduced into each solution and incubated under rocking condition for $24 \mathrm{~h}$. To evaluate the toxicity of the solution, counting of larvae viability was performed under microscope by determining the number of dead larvae in each solution. In the case where there was death in the control medium, the data was corrected by Abbott's formula:

$\%$ death $=[($ nd test - nd control $) /$ nd control $)] 9100$ (Abott, 1925). nd : number of dead larvae.

Data (dose-response) were transformed by logarithm and the halflethal concentration $\mathrm{LC}_{50}$ was determined by linear regression (Hafner et al., 1977). Tests were carried out in triplicates. All data were expressed as mean \pm standard deviation of triplicate measurements.

\section{RESULTS AND DISCUSSION}

We have synthesized two series of derivatives hydrazones in goods yields $(57-91 \%)$. There are: S-(+)-carvone salicylhydrazone (GS1), 4'-methylacetophenone salicylhydrazone (GS2), 7-methoxy-1-tetralone salicylhydrazone (GS3) and 2acetylnaphthalene salicylhydrazone (GS4) ; S-(+)-carvone $p$ tosylhydrazone (GT1), 4'-methylacetophenone $p$-tosylhydrazone (GT2), 7-methoxy-1-tetralone $p$-tosylhydrazone (GT3) and 2acetylnaphthalene $p$-tosylhydrazone (GT4).

The hydrazine or hydrazide having the same radical $\mathrm{H}_{2} \mathrm{~N}-\mathrm{NH}-\mathrm{R}$ reacts with a carbonyl compound according to the same mechanism. Steric and electronic effects of the various substituents of the carbonyl are responsible for the difference in reactivity and yields when the same hydrazine derivative is reacted with various substrates and vice versa.

In the literature, it was described in 1976 the synthesis of acetophenone $p$-tosylhydrazone without catalyst for 5.5 hours with 68\% yield (Ashraf, 1976); the synthesis using benzaldehyde salicylic acid hydrazide and 4-dimethylaminobenzaldehyde or 4nitrobenzaldehyde for 4 hours (Al-Ajrawy, 2011). To enhance the reaction, we used during our work in the synthesis of the salicylhydrazones (GSn) and $p$-tosylhydrazones (GTn) the glacial acetic acidic and technical ethanol. The mixture is heated to reflux for 2 hours and the reaction followed by TLC with yields ranging from 57 to $90 \%$. The low yield $57 \%$ obtained of S-(+)-carvone $p-$ tosylhydrazone (GT1) is due to the nature of this $\alpha-\beta$ unsaturated ketone. We note well the presence of adduct 1-4 minority (Michael addition) which was removed after purification.

The scaffold has advantageous properties : low molecular weight, reasonable $C \log P$, good hydrogen bond donating and accepting capabilities (table 1), easy, and economical synthetic routes (Lipinski et al., 1997)..

The structures of synthesized compounds were characterized with the TLC frontal rapport $\left(\mathrm{R}_{\mathrm{f}}\right)$, spectrometrical analysis MS, especially with NMR ${ }^{1} \mathrm{H} \&{ }^{13} \mathrm{C}$.

Table 1 : Properties Compatible with Reasonable Pharmacokinetics and Drug Availability, Rules of Lipinski et al., (1997) applied to hydrazones.

\begin{tabular}{cccccc}
\hline Compounds & $\begin{array}{l}\text { Molecular weight } \\
\text { (g.mol-1) }\end{array}$ & $\begin{array}{l}\boldsymbol{C} \\
\boldsymbol{l o g} \boldsymbol{P}\end{array}$ & $\begin{array}{l}\text { No. of } \\
\text { H bond } \\
\text { donors }\end{array}$ & $\begin{array}{l}\text { No. of } \\
\text { H bond } \\
\text { acceptors }\end{array}$ & $\begin{array}{l}\text { No. of } \\
\text { criteria } \\
\text { met }\end{array}$ \\
\hline Rules & $<\mathbf{5 0 0}$ & $<\mathbf{5}$ & $\leq \mathbf{5}$ & $<\mathbf{1 0}$ & $\begin{array}{c}\text { At least 3 } \\
\text { GS1 }\end{array}$ \\
GS4.35 & 3.093 & 2 & 4 & all \\
GS2 & 268.31 & 2.436 & 2 & 4 & all \\
GS3 & 310.34 & 2.358 & 2 & 5 & all \\
GS4 & 304.34 & 3.111 & 2 & 4 & all \\
GT1 & 318.43 & 4.772 & 1 & 4 & all \\
GT2 & 302.39 & 4.115 & 1 & 4 & all \\
GT3 & 344.43 & 4.199 & 1 & 5 & all \\
GT4 & 338.42 & 4.790 & 1 & 4 & all \\
\hline
\end{tabular}

\section{Characterization of synthesized compounds}

\section{S-(+)-carvone salicylhydrazone (GS1) (Figure 1)}

Yield : $78 \%$; m.p. : $189-190^{\circ} \mathrm{C} ; \mathrm{R}_{\mathrm{f}}(\mathrm{Hex} / \mathrm{AcOEt}, \mathrm{v} / \mathrm{v}$, $7 / 3): 0.57 ; \mathrm{NMR}^{13} \mathrm{C}\left(\mathrm{DMSO}^{-\mathrm{d}_{6}}, \delta\right.$ in ppm) $: 161,78$ (N-CO-Ar); $147.53(\mathrm{C}=\mathrm{N}) ; 156.36$ (C-OH phenolic); 133.87, 130.45, 119.59, $117.95,116.77$ (other C-Ar); 153.99, 133.16, 132.28, 110.32, 40.10, 29.57, 29.45, 20.44, 17.85 (C-carvone).

NMR ${ }^{1} \mathrm{H}\left(\right.$ DMSO- $_{6}, \delta$ in ppm) : $11.75(\mathrm{~s}, 1 \mathrm{H}, \mathrm{OH}) ; 11.20(\mathrm{~s}, 1 \mathrm{H}$, $\mathrm{NH})$; 7.97-6.95 (m, 4H, H-Ar); 6.25 (t, $1 \mathrm{H}, \mathrm{C}=\mathrm{CH}-)$; $4.84(\mathrm{~d}, 2 \mathrm{H}$, $\left.\mathrm{C}=\mathrm{CH}_{2}\right) ; 2.75\left(\mathrm{qi}, 1 \mathrm{H}, \mathrm{CH}_{2}-\mathrm{CH}-\mathrm{CH}_{2}\right) ; 2.45$ (t, $2 \mathrm{H}, \mathrm{C}=\mathrm{CH}-\mathrm{CH}_{2}-$ $\mathrm{CH}) ; 2.25\left(\mathrm{~d}, 2 \mathrm{H}, \mathrm{HC}-\mathrm{CH}_{2}-\mathrm{C}=\mathrm{N}\right) ; 1.90\left(\mathrm{~s}, 3 \mathrm{H}, \mathrm{CH}_{3}\right) ; 1.78(\mathrm{~s}, 3 \mathrm{H}$, $\mathrm{CH}_{3}$ ).

MS m/z [MH $\left.{ }^{+}\right]$found : 285.37 ; [M]theoretical : 284.35 ; Molecular formula : $\mathrm{C}_{17} \mathrm{H}_{20} \mathrm{~N}_{2} \mathrm{O}_{2}$

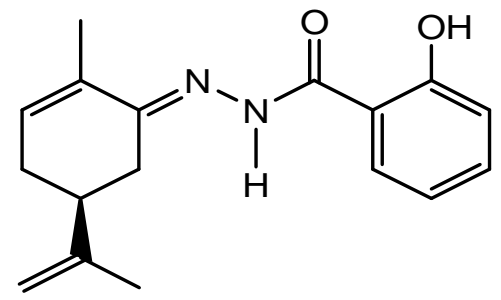

Fig. 1: S-(+)-carvone salicylhydrazone (GS1). 


\section{4'-methylacetophenone salicylhydrazone (GS2) (Figure 2)}

Yield : $79 \%$; m.p. : $237-238^{\circ} \mathrm{C} ; \mathrm{R}_{\mathrm{f}}(\mathrm{Hex} / \mathrm{AcOEt}, \mathrm{v} / \mathrm{v}$, $7 / 3): 0.63$; NMR ${ }^{13} \mathrm{C}$ (DMSO-d ${ }_{6}, \delta$ in ppm): 163.14 (N-CO-Ar); $153.51(\mathrm{C}=\mathrm{N}) ; 157.67$ (C-OH phenolic); 140.18, 136.27, 134.47, $131.69,130.12,127.52,120.82,119.02,118.01$ (other $\mathrm{C}-\mathrm{Ar}$ ); $21.99\left(\mathrm{H}_{3} \mathrm{C}-\mathrm{Ar}\right) ; 14.93\left(\mathrm{CH}_{3}\right)$.

NMR ${ }^{1} \mathrm{H}\left(\right.$ DMSO-d $_{6}, \delta$ in ppm): $11.80(\mathrm{~s}, 1 \mathrm{H}, \mathrm{OH}) ; 11.30$ (s, 1H, NH); 8.00-6.97 (m, 8H, H-Ar); 2.45 (s, 3H, $\mathrm{H}_{3} \mathrm{C}-\mathrm{Ar}$ ), 2.31 (s, $3 \mathrm{H}, \mathrm{CH}_{3}$ ).

$\mathrm{MS} \mathrm{m} / \mathrm{z}\left[\mathrm{MH}^{+}\right]$found : 269.27 ; [M]theoretical : 268.31 ; Molecular formula : $\mathrm{C}_{16} \mathrm{H}_{16} \mathrm{~N}_{2} \mathrm{O}_{2}$

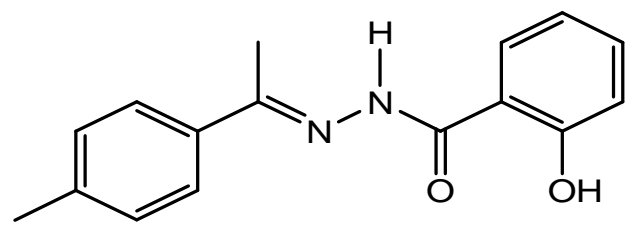

Fig. 2: 4'-methylacetophenone salicylhydrazone (GS2)

\section{7-methoxy-1-tetralone salicylhydrazone (GS3) (Figure 3)}

Yield : $85 \%$; m.p. : $223-224^{\circ} \mathrm{C}$; $\mathrm{R}_{\mathrm{f}}(\mathrm{Hex} / \mathrm{AcOEt}$, v/v, $7 / 3): 0.47$; NMR ${ }^{13} \mathrm{C}$ (DMSO-d ${ }_{6}, \delta$ in ppm): 161.82 (N-CO-Ar); $151.75(\mathrm{C}=\mathrm{N}) ; 157.64\left(\mathrm{C}-\mathrm{OH}\right.$ phenolic); $156.42\left(\mathrm{C}_{\mathrm{Ar}}-\mathrm{OCH}_{3}\right)$; 133.31, 133.04, 132.56, 130.57, 129.62, 119.69, 117.90, 116.83, $116.35,108.18$ (other C-Ar); $55.10\left(\mathrm{O}-\mathrm{CH}_{3}\right) ; 27.92,25.55,21.53$ (3s, 6H, 3“- $\left.\mathrm{CH}_{2}-"\right)$.

NMR ${ }^{1} \mathrm{H}$ (DMSO-d ${ }_{6}, \delta$ in ppm): $11.80(\mathrm{~s}, 1 \mathrm{H}, \mathrm{OH}) ; 11.33$ (s, 1H, NH); 8.00-6.90 (m, 7H, H-Ar); 3.80 (s, 3H, O- $\left.\mathrm{CH}_{3}\right) ; 3.35$, 2.69, $1.89\left(\mathrm{~s}, 6 \mathrm{H}, 3 \mathrm{CH}_{2}\right)$.

MS m/z $\left[\mathrm{MH}^{+}\right]$found : $311.33 ;[\mathrm{M}]$ theoretical : 310.34 ; Molecular formula : $\mathrm{C}_{18} \mathrm{H}_{18} \mathrm{~N}_{2} \mathrm{O}_{3}$

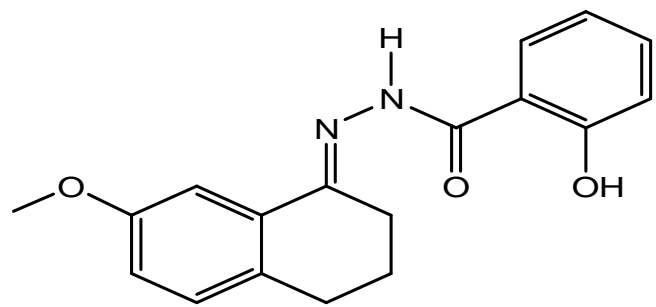

Fig. 3: 7-methoxy-1-tetralone salicylhydrazone (GS3)

\section{2-acetynaphthalene salicylhydrazone (GS4) (Figure 4)}

Yield : $91 \%$; m.p. : $241-242^{\circ} \mathrm{C} ; \mathrm{R}_{\mathrm{f}}(\mathrm{Hex} / \mathrm{AcOEt}, \mathrm{v} / \mathrm{v}$, $7 / 3): 0.33 ; \mathrm{NMR}^{13} \mathrm{C}$ (DMSO-d $\mathrm{D}_{6}, \delta$ in ppm) : 162.01 (N-CO-Ar); $151.83(\mathrm{C}=\mathrm{N})$; $156.47(\mathrm{C}-\mathrm{OH}$ phenolic); 135.26, 133.39, 133.28, $133.05,132.74,130.66,128.54,127.73,127.48,126.89,123.63$, 119.72, 117.92, 116.87 (other C-Ar); $13.60\left(\mathrm{CH}_{3}\right)$.

NMR ${ }^{1} \mathrm{H}\left(\mathrm{DMSO}_{\mathrm{d}}, \delta\right.$ in ppm): $11.80(\mathrm{~s}, 1 \mathrm{H}, \mathrm{OH}) ; 11.42(\mathrm{~s}, 1 \mathrm{H}$, $\mathrm{NH})$; 8.36-7.05 (m, 11H, H-Ar); 2.33 (s, 3H, $\mathrm{CH}_{3}$ ).

MS m/z $\left[\mathrm{MH}^{+}\right]$found : $305.32 ;[\mathrm{M}]$ theoretical : 304.34 ; Molecular formula : $\mathrm{C}_{19} \mathrm{H}_{16} \mathrm{~N}_{2} \mathrm{O}_{2}$.

Analyses of the ${ }^{13} \mathrm{C}$ NMR spectra of this series of hydrazones show the peak of the amide carbon function $(\mathrm{N}-\mathrm{CO}$ -
Ar) between 163 and 161 ppm. The carbon of the imine's function, characteristic group obtaining during the reaction $(\mathrm{C}=\mathrm{N})$ appears around 153-147 ppm. Other peaks between 158 and $108 \mathrm{ppm}$ correspond to the aromatic ring; phenolic carbon (aromatic $\mathrm{C}-\mathrm{OH}$ ) has a high value between 157 and 156 ppm. In ${ }^{1} \mathrm{H}$ NMR, there are two types of protons: the phenolic $\mathrm{OH}$ proton and that of $\mathrm{NH}$. The phenolic $\mathrm{OH}$ proton having acidic properties and may establish a hydrogen bond with the carbonyl in ortho is to a lower field than the NH proton (Baligar and Revankar, 2006; Govindasami et al., 2011). So it will be assigned to $\mathrm{OH}$, the higher $\delta$ value. Therefore, it is a singlet between 11.80 and $11.75 \mathrm{ppm}$ whereas the $\mathrm{NH}$ proton singlet occurs at 11.42 to $11.20 \mathrm{ppm}$. The aromatic protons appear between 8.36 and $6.90 \mathrm{ppm}$.

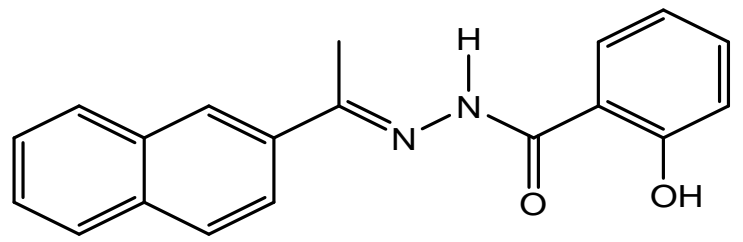

Fig. 4: 2-acetynaphthalene salicylhydrazone (GS4)

\section{S-(+)-carvone $p$-tosylhydrazone (GT1) (Figure 5)}

Yield : $57 \%$; m.p. : $167-168^{\circ} \mathrm{C}$; $\mathrm{R}_{\mathrm{f}}(\mathrm{Hex} / \mathrm{AcOEt}, \mathrm{v} / \mathrm{v}$, $8 / 2): 0.46 ; \mathrm{NMR}^{13} \mathrm{C}\left(\mathrm{CDCl}_{3}, \delta\right.$ in ppm $): 154.80(\mathrm{C}=\mathrm{N}) ; 144.02$, 132.46, 129.38, 128.26 (C-Ar); 147.11, 135.17, 133.59, 110.40, 40.36, 29.96, 29.09, 21.64, 17.65 (C-carvone); 20.65 ( $\left.\mathrm{H}_{3} \mathrm{C}-\mathrm{Ar}\right)$. $\mathrm{NMR}{ }^{1} \mathrm{H}\left(\mathrm{CDCl}_{3}, \delta\right.$ in ppm) : $7.90(\mathrm{~s}, 1 \mathrm{H}, \mathrm{NH}) ; 7.65 \& 7.30(2 \mathrm{~s}$, $4 \mathrm{H}, \mathrm{H}-\mathrm{Ar}) ; 6.05$ (t, 1H, C=CH-); $4.75\left(\mathrm{dd}, 2 \mathrm{H}, \mathrm{C}=\mathrm{CH}_{2}\right) ; 2.60(\mathrm{~m}$, $\left.1 \mathrm{H}, \mathrm{CH}_{2}-\mathrm{CH}-\mathrm{CH}_{2}\right) ; 2.45\left(\mathrm{t}, 2 \mathrm{H}, \mathrm{C}=\mathrm{CH}-\mathrm{CH}_{2}-\mathrm{CH}\right) ; 2.25(\mathrm{~d}, 2 \mathrm{H}$, $\left.\mathrm{HC}-\mathrm{CH}_{2}-\mathrm{C}=\mathrm{N}\right) ; 1.95\left(\mathrm{~m}, 3 \mathrm{H}, \mathrm{CH}_{3}\right) ; 1.77\left(\mathrm{~s}, 3 \mathrm{H}, \mathrm{CH}_{3}\right) ; 1.70(\mathrm{~s}, 3 \mathrm{H}$, $\mathrm{CH}_{3}$ ).

MS m/z $\left[\mathrm{MH}^{+}\right]$found : $319.33 ;[\mathrm{M}]$ theoretical : 318.43 ; Molecular formula : $\mathrm{C}_{17} \mathrm{H}_{22} \mathrm{~N}_{2} \mathrm{O}_{2} \mathrm{~S}$

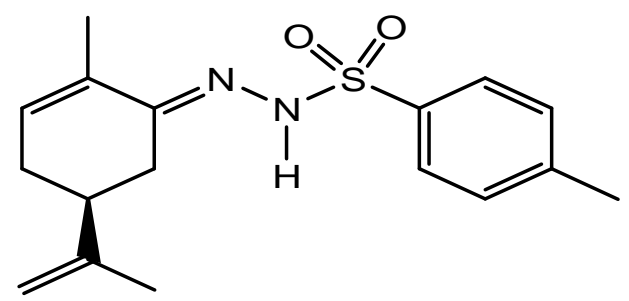

Fig. 5: S-(+)-carvone $p$-tosylhydrazone (GT1)

\section{4'-methylacetophenone $\boldsymbol{p}$-tosylhydrazone (GT2) (Figure 6)}

Yield : $81 \%$; m.p. : $190-191{ }^{\circ} \mathrm{C}$; $\mathbf{R}_{\mathbf{f}}(\mathrm{Hex} / \mathrm{AcOEt}, \mathrm{v} / \mathrm{v}$, $7 / 3): 0.51 ; \mathrm{NMR}^{13} \mathrm{C}\left(\mathrm{DMSO}-\mathrm{d}_{6}, \delta\right.$ in ppm) : $153.17(\mathrm{C}=\mathrm{N})$; 143.26, 138.98, 136.21, 134.62, 129.40, 128.90, 127.57, 125.86 (C-Ar); 20.97, $20.75\left(\mathrm{H}_{3} \mathrm{C}-\mathrm{Ar}\right) ; 14.17\left(\mathrm{CH}_{3}\right)$.

NMR ${ }^{1} \mathrm{H}\left(\right.$ DMSO$_{-} \mathrm{d}_{6}, \delta$ in ppm) : 10.45 (s, 1H, NH); 7.82-7.15 (m, $8 \mathrm{H}, \mathrm{H}-\mathrm{Ar}$ ); 2.37 (s, 3H, H $\mathrm{H}_{3} \mathrm{C}-\mathrm{Ar}$ ); 2.30 (s, 3H, $\mathrm{H}_{3} \mathrm{C}-\mathrm{Ar}$ ); 2.17 (s, $\left.3 \mathrm{H}, \mathrm{CH}_{3}\right)$.

MS m/z [MH $\left.{ }^{+}\right]$found : 303.37 ; [M]theoretical : 302.39 ; Molecular formula : $\mathrm{C}_{16} \mathrm{H}_{18} \mathrm{~N}_{2} \mathrm{O}_{2} \mathrm{~S}$ 
<smiles>C/C(=N\NS(=O)(=O)c1ccc(C)cc1)c1ccc(C)cc1</smiles>

Fig. 6 : 4'-methylacetophenone $p$-tosylhydrazone (GT2)

\section{7-methoxy-1-tetralone $p$-tosylhydrazone (GT3) (Figure 7)}

Yield : $90 \%$; m.p. : $200-201{ }^{\circ} \mathrm{C}$; $\mathrm{R}_{\mathrm{f}}(\mathrm{Hex} / \mathrm{AcOEt}, \mathrm{v} / \mathrm{v}$, $8 / 2): 0.17 ; \mathrm{NMR}^{13} \mathrm{C}\left(\mathrm{CDCl}_{3}, \delta\right.$ in ppm $): 152.57(\mathrm{C}=\mathrm{N}) ; 157.99$ $\left(\mathrm{C}_{\mathrm{Ar}}-\mathrm{OCH}_{3}\right) ; 144.20,135.42,132.42,132.41,129.57,129.42$, 128.23, 117.08, 108.21 (other C-Ar); $55.30\left(\mathrm{O}-\mathrm{CH}_{3}\right) ; 28.43,25.31$, $21.64\left(3 \mathrm{CH}_{2} \& 1 \mathrm{CH}_{3}\right)$.

$\mathrm{NMR}{ }^{1} \mathrm{H}\left(\mathrm{CDCl}_{3}, \delta\right.$ in ppm $): 8.10(\mathrm{~s}, 1 \mathrm{H}, \mathrm{NH}) ; 7.91-6.84$ (m, 7H, H-Ar); 3.85 (s, 3H, $\left.\mathrm{H}_{3} \mathrm{C}-\mathrm{O}\right) ; 2.63,2.45,1.83(\mathrm{~m}, 6 \mathrm{H}$, $\left.3 \mathrm{CH}_{2}\right) ; 2.34$ (s, 3H, $\mathrm{H}_{3} \mathrm{C}-\mathrm{Ar}$ ).

MS m/z [MH $\left.\mathrm{MH}^{+}\right]$found : $345.41 ;[\mathrm{M}]$ theoretical : 344.43 ; Molecular formula : $\mathrm{C}_{18} \mathrm{H}_{20} \mathrm{~N}_{2} \mathrm{O}_{3} \mathrm{~S}$

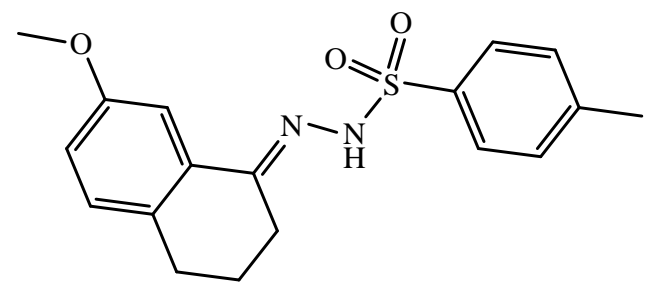

Fig. 7: 7-methoxy-1-tetralone $p$-tosylhydrazone (GT3)

\section{2-acetylnaphthalene $p$-tosylhydrazone (GT4) (Figure 8)}

Yield : $74 \%$; m.p. : $181-182^{\circ} \mathrm{C} ; \mathrm{R}_{\mathrm{f}}(\mathrm{Hex} / \mathrm{AcOEt}, \mathrm{v} / \mathrm{v}$, $7 / 3): 0.23$; $\mathrm{NMR}^{13} \mathrm{C}\left(\mathrm{CDCl}_{3}, \delta\right.$ in ppm $): 152.37(\mathrm{C}=\mathrm{N}) ; 144.26$, $135.42,134.67,133.85,132.88,129.67,128.58,128.19,128.04$, 127.64, 126.92, 126.42, 126.29, 123.56 (C-Ar); $21.64\left(\mathrm{H}_{3} \mathrm{C}-\mathrm{Ar}\right)$; $13.29\left(\mathrm{CH}_{3}\right)$.

NMR ${ }^{1} \mathrm{H}\left(\mathrm{CDCl}_{3}, \delta\right.$ in ppm) : $8.10(\mathrm{~s}, 1 \mathrm{H}, \mathrm{NH}) ; 7.93-7.25(\mathrm{~m}, 11 \mathrm{H}$, $\mathrm{H}-\mathrm{Ar}) ; 2.39$ (s, 3H, $\left.\mathrm{H}_{3} \mathrm{C}-\mathrm{Ar}\right) ; 2.25$ (s, 3H, $\mathrm{CH}_{3}$ ).

MS m/z [MH $\left.{ }^{+}\right]$found : $339.38 ;[\mathrm{M}]$ theoretical : 338.42 ; Molecular formula : $\mathrm{C}_{19} \mathrm{H}_{18} \mathrm{~N}_{2} \mathrm{O}_{2} \mathrm{~S}$

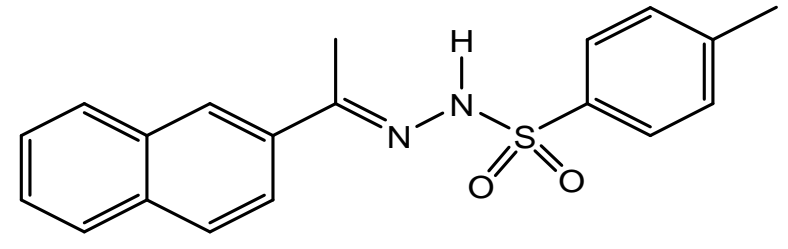

Fig. 8: 2-acetylnaphthalene $p$-tosylhydrazone (GT4).
In this series of compounds, ${ }^{13} \mathrm{C}$ NMR spectral' analyses presented the group $\mathrm{C}=\mathrm{N}$ characteristic of the formation of products between 154 and $152 \mathrm{ppm}$. Aromatic carbons are in the region 144-108 ppm, depending on the structure of the test compound. We remark in ${ }^{1} \mathrm{H} \mathrm{NMR}$, the single proton of the internal nitrogen $\mathrm{NH}$ is in the form of a singlet at $10.45 \mathrm{ppm}$ for the 4'-methylacetophenone $p$-tosylhydrazone (GT2) in DMSO- $\mathrm{d}_{6}$ and $8.10 \mathrm{ppm}$ (GT3 \& GT4) and $7.90 \mathrm{ppm}$ (GT1) ppm in $\mathrm{CDCl}_{3}$. This difference is due to the effect of DMSO solvent which generates a strong hydrogen bond between oxygen and the $\mathrm{NH}$ proton (Silverstein et al., 2007) causing a chemical shift of hydrogen downfield. Aromatic protons are observed as bedding from 7.93 to $6.84 \mathrm{ppm}$. The molar mass of each synthesized molecule given by mass spectrometry is consistent with theoretical mass found. Various spectrometrical analyses done on each compound have really confirmed the presence of functional groups and different types of protons and carbons in each structure. The spectrometric data are in conformity with the structures suggested for the products.

\section{Pharmacology}

Anti-parasitic activity of compounds was evaluated in vitro on the bloodstream form of the strain 427 of Trypanosome brucei brucei and their toxicity on larvae of Artemia salina L. The half-inhibitory concentration $\left(\mathrm{IC}_{50}\right)$ and half-lethal concentration $\left(\left(\mathrm{LC}_{50}\right)\right.$ were respectively determined and expressed in microlar $(\mu \mathrm{M})$ to be compared with the scales of trypanocidal and toxic activities. And then, the selectivity index (SI) of each compound was calculated. The results are reported in table 2.

According to the works of Du et al., 2002 and Fujii et al., 2005 studying thiosemicarbazones, compounds that have $\mathrm{IC}_{50}$ values below $10 \mu \mathrm{M}$ can be considered as trypanocidal molecules, when $\mathrm{IC}_{50}$ values are between 10 and $100 \mu \mathrm{M}$, they are considered as moderate antitrypanosomal. The compounds which have their $\mathrm{IC}_{50}$ higher than $100 \mu \mathrm{M}$ showed little or no activity.

In our work, we note that compounds 2acetylnaphthalene salicylhydrazones GS4 and 7-methoxy-1 tetralone $p$-tosylhydrazone GT3 exhibited a trypanocidal activity $\left(\mathrm{IC}_{50}=1.97 \pm 0.42\right.$ and $7.98 \pm 1.65 \mu \mathrm{M}$ respectively $)$ when other except GT2 $\left(\mathrm{IC}_{50}>100 \mu \mathrm{M}\right.$, low activity) showed moderate trypanocidal activity $\left(11<\mathrm{IC}_{50}<34 \mu \mathrm{M}\right)($ table 2$)$.

Indeed, $\mathrm{Du}$ et $a l$. found that macrophage cells are generally sensitive to concentrations above $10 \mu \mathrm{M}$ of thiosemicarbazones.

Table 2: Trypanocidal, toxic activity and selectivity index of synthesized hydrazones.

\begin{tabular}{|c|c|c|c|c|c|}
\hline Compounds & IC50 $(\mu \mathrm{M})$ & Activity & $\operatorname{LC50}(\mu \mathrm{M})$ & Toxicity & Selectivity index (SI = LC50 / IC50) \\
\hline GS1 & $18.42 \pm 0.80$ & Moderate & $219.44 \pm 2.17$ & toxic & 11.91 \\
\hline GS2 & $20.53 \pm 0.74$ & Moderate & $352.57 \pm 1.32$ & no toxic & 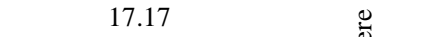 \\
\hline GS3 & $11.11 \pm 1.77$ & Moderate & $731.13 \pm 3.27$ & no toxic & 3 \\
\hline GS4 & $1.97 \pm 0.42$ & Trypanocidal & $310.50 \pm 1.93$ & no toxic & $-\stackrel{\infty}{\Xi}: \stackrel{0}{\Xi}$ \\
\hline GT1 & $23.99 \pm 5.11$ & Moderate & $536.38 \pm 2.35$ & no toxic & $\hat{\theta} \overrightarrow{0}$ \\
\hline GT2 & IC50 > 100 & Little or no & $368.06 \pm 1.87$ & no toxic & ¿ूं \\
\hline GT3 & $7.98 \pm 1.65$ & Trypanocidal & $137.32 \pm 0.77$ & toxic & 17.20 \\
\hline GT4 & $33.62 \pm 7.29$ & Moderate & $35.45 \pm 1.41$ & toxic & 1.05 \\
\hline
\end{tabular}


Thus, in addition to inhibiting property of the parasite, they would preserve the human macrophage host cell (Du et al., 2002 ; Fujii et al., 2005). On this basis, hydrazones GS4 (1.97 \pm $0.42 \mu \mathrm{M})$ and GT3 $(7.98 \pm 1.65 \mu \mathrm{M})$ were selected as good trypanocidal compounds. It remarks in this study that salicylhydrazones synthesized GS1-4, $\mathrm{IC}_{50}$ ranging from 1 to 21 $\mu \mathrm{M}$, were more trypanocidal than their analogues $p$ tosylhydrazones GT1-4 $\left(\mathrm{IC}_{50}=7\right.$ to $\left.>100 \mu \mathrm{M}\right)$.

The toxicity study showed that only compounds GS1, GT3 and GT4 $\left(\mathrm{LC}_{50}=219.44,137.32\right.$ and $35.45 \mu \mathrm{M}$ respectively) exerted a toxic activity whereas the other presented no effect $\left(\mathrm{LC}_{50}\right.$ $>281 \mu \mathrm{M}$ ) on larvae of Artemia salina. To assess the toxicity with the $\mathrm{LC}_{50}$ values of compounds (table 2), we have referred to the $\mathrm{LC}_{50}$ value of lapachol $\left(\mathrm{LC}_{50}=281 \mu \mathrm{M}\right)$ which is known as reference compound (Graminha et al., 2008; Santos et al., 2003). These tests that are a summary assessment of the toxicity of products reflects the sensitivity of shrimp larvae to the synthesized compounds and by extension that of the human species. Indeed, there is a correlation between toxicity on shrimp larvae and cytotoxicity on cells 9KB and 9PS (human carcinoma nasopharygien) a part (Pelka et al., 2000), cells A-549 lung carcinoma and HT-29 cells of carcinoma of the colon on the other (Carballo et al., 2002). Thus, the three toxic products would exert activity on the cells.

From the analyses of their selectivity index $(1<\mathrm{SI}<$ 140), we note that all products turn out quite selective on the parasite Trypanosoma brucei brucei. These results are in perfect agreement with the work of Tiuman et al., (2005) in which if the SI value obtained is greater than unity, the test compound is considered to be selective on the parasite and if SI value is less than unity, the test compound is more cytotoxic than anti-parasitic. Especially, some of the group: the salicylhydrazones of 2acetylnaphthalene GS4, 7-methoxy-1-tetralone GS3 (SI = 157, 65 respectively), S-(+)-carvone $p$-tosylhydrazone GT1 $(\mathrm{SI}=22)$ were the most selective. Based on the different tests values, it appears that the $\mathrm{S}$-(+)-carvone $p$-tosylhydrazone GT1 and the salicylhydrazones obtained from 4'-methylacetophenone GS2, 7methoxy-1-tetralone GS3 and 2-acetylnaphthalene GS4 exhibited significant trypanocidal activity without effect on Artemia salina L. and selective would be able to be used at higher doses for trypanosomiasis treatment.

\section{CONCLUSION}

In this study, eight hydrazones derivatives were synthesized and characterized. Their biological activities were evaluated and products showed interesting trypanocidal activity on the parasite study and were selective. To our knowledge, this is the first time these molecules are synthesized and their antiparasitic evaluated on Trypanosoma brucei brucei and then they could open an interesting opportunity to the treatment of trypanosome.

Acknowledgments: This study was possible to financial and technical support of the Belgium Kingdom through the BTC that we thank very sincerely. We also thank Professor D. Lambert and all the staff of LDRI at the Universite Catholique de Louvain, Brussels, Belgium.

\section{REFERENCES}

Abbott WA. A method of computing the effectiveness of an insecticide. J Econ Entomol, 1925; 18: 265.

Al-Ajrawy OIH. Preparation, Characterization of $\mathrm{Mn}(\mathrm{II})$, $\mathrm{Mn}$ (III) and Mn(IV) Complexes with Schiff Base Ligands Derived from Salicylic acid Hydrazide have N,O Donors and Biological Activity Study. Al-Anbar J Vet Sci, 2011; 4(2): 129-135.

Ali R, Marella A, Alam T, Naz R, Akhter M, Shaquiquzzaman, Saha R, Tanwar O, Alam M, Hooda J. Review of biological activities of hydrazones. Indonesian J Pharm, 2012; 23(4): 193-202.

Ashraf M. Thermolysis of the sodium salt of tricarbonyl(acetophenone)chromium p-tosylhydrazone. Can J Chem, 1976; 54: 448-454.

Badiger DS, Hunoor RS, Patil BR, Vadavi RS, Mangannavar CV, Muchchandi IS, Patil YP, Nethaji M, Gudasi KB. Synthesis, spectroscopic properties and biological evaluation of transition metal complexes of salicylhydrazone of anthranilhydrazide: X-ray crystal structure of copper complex. Inorganica Chim Acta, 2012; 384: 197-203.

Baligar R Revankar V. Coordination diversity of new mononucleating hydrazone in 3d metal complexes: Synthesis, characterization and structural Studies. J Serb Chem Soc, 2006; 71(12): 1301-1310.

Baltz T, Baltz D, Giroud C, Crockett J. Cultivation in a semi defined medium of animal infective forms of Trypanosoma brucei, $T$. equiperdum, T. evansi, T. rhodhesiense et T. gambiense. EMBO J, 1985, 4(5): 1273-1277.

Bedia KK, Elçin O, Seda U, Fatma K, Nathaly S, Sevim R, Dimoglo A. Synthesis and characterization of novel hydrazide-hydrazones and the study of their structure-antituberculosis activity. Eur J Med Chem, 2006; 41: 1253-1261.

Carballo JL, Hernández-Inda ZL, Pérez P, García-Grávalos DC. A comparison between two brine shrimp assays to detect in vitro cytotoxicity in marine natural products. BMC Biotechnol, 2002; 17. doi: 10.1186/1472-6750-2-17.

Cocco MT, Congiu C, Lilliu V, Onnis V. Syn-thesis and in vitro Antitumoral Activity of New Hy-drazinopyrimidine-5-carbonitrile Derivatives. Bioorg Med Chem, 2006; 14(2): 366-372. doi: 10.1016/j.bmc.2005.08.012

Cui Z, Yang X, Shi Y, Uzawa H, Cui J, Dohi H, Nishida Y. Molecular design, synthesis and bioactivity of glycosyl hydrazine and hydrazone derivatives: notable effects of the sugar moiety. Bioorg Med Chem Lett, 2011; 21(23): 7193-7196. doi: 10.1016/j.bmcl.2011.09.068.

Du X, Guo C, Hansell E, Doyle SP, Caffrey CR, Holler TP, McKerrow JH, Cohen FE. Synthesis and Structure-Activity Relationship Study of Potent Trypanocidal thiosemicarbazone Inhibitors of the Trypanosomal Cysteine Protease Cruzain. J Med Chem, 2002; 45: 2695 2707.

El-Sabbagh OI, Rady HM. Synthesis of new acridines and hydrazones derived from cyclicâ-diketone for cytotoxic and antiviral evaluation. Eur J Med Chem, 2009; 44: 3680-3686. doi: 10.1002/chin. 200948062.

El-Tabl AS, El-Saied FA, Al-Hakimi AN. Spectroscopic characterization and biological activity of metal complexes with an ONO trifunctionalized hydrazone ligand. J Coord Chem, 2008; 61: 2380-2401.

Friedman L, Litle RL, Reichle WR. p-toluenesulfonylhydrazide [ $p$-toluenesulfonic acid, hydrazide]. Org Syntheses, 1960; 40:93. doi: 10.15227/orgsyn.040.0093

Fujii N, Mallari JP, Hansell EJ, Mackey Z, Doyle P, Zhou YM, Gut J, Rosenthal PJ, McKerrow JH, Guy RK. Discovery of potent thiosemicabazones inhibitors of rhodesain and cruzain. Bioorg Med Chem, 2005; 15(1): 121-123.

Govindasami T, Pandey A, Palanivelu N, Pandey A. Synthesis, characterization and antibacterial activity of biologically important vanillin related hydrazone derivatives. Int J Org Chem, 2011; 1: 71-77. 
Graminha AE, Batista AA, Louro SRW, Ziolli RL, Teixeira LR, Beraldo H. 2-Pyridinoformamide-derived thiosemicarbazones and their iron(III) complexes : potential antineoplastic activity. Polyhedron, 2008; 27: 547-551.

Hafner E, Heiner E, Noack E. Mathematical analysis of concentration-response relationships. Arzneim-Forsch Drug Res, 1977; 27: 1871-1873.

Hassanien MM, Gabr IM, Abdel-Rhman MH, El-Asmy AA. Synthesis and structural investigation of mono- and polynuclear copper complexes of 4-ethyl-1-(pyridin-2-yl) thiosemicarbazide. Spectrochimica Acta A, 2008, 71: 73-79.

Kaushik D, Khan SA, Chawla G, Kumar S. N'-[(5-chloro-3methyl-1-phenyl-1H-pyrazol-4-yl) methylene] 2/4-substituted hydrazides: Synthesis and anticonvulsant activity. Eur J Med Chem, 2010; 45: $3943-$ 3949. doi: 10.1016/j.ejmech.2010.05.049.

Küçükgüzel SG, Mazi A, Sahin F, Öztürk S, Stables JP. Synthesis and Biological Activities of Diflunisal Hydrazide-Hydrazones. Eur J Med Chem, 2003; 38(11): 1005-1013. doi:10.1016/j.ejmech.2003.08.004.

Lipinski CA, Lombardo F, Dominy BW, Feeney PJ. Experimental and Computational Approaches to Estimate Solubility and Permeability in Drug Discovery and Development Settings. Adv Drug Delivery Rev, 1997; 23: 3-25.

Loncle C, Brunel JM, Vidal N, Dherbomez M, Letourneux Y. Synthesis and Antifungal Activity of Cholesterol-Hydrazone Derivatives. Eur J Med Chem, 2004; 39(12): 1067-1071. doi: 10.1016/j.ejmech.2004.07.005.

Melnyk P, Leroux V, Sergheraert C. Grellier P. Design, Synthesis and in vitro Antimalarial Activity of an Acylhydrazone Library. Bioorg Med Chem Lett, 2006; 16(1): 31-35. doi:10.1016/j.bmcl.2005.09.058.

Narasimhan B, Kumar P, Sharma D. Biological activities of hydrazide derivatives in the new millennium. Acta Pharma Sci, 2010; 52: 169-180.

Özkay Y, Tunali Y, Karaca H, Isikdag I. Antimicrobial activity and a SAR study of some novel benzimidazole derivatives bearing hydrazone moiety. Eur J Med Chem, 2010; 45: 3293-3298.

Pelka M, Danzl C, Distler W, Petschelt A. A new screening test for toxicity testing of dental materials. J Dent, 2000; 28(5): 341-345.

Räz B, Iten M, Grether-Bühler Y., Kaminsky R., Brun R. The Alamar Blue $\mathrm{T}^{\mathrm{TM}}$ assay to determine drugs sensitivity of African trypanosomes (Trypanosoma brucei rhodesiense and Trypanosoma brucei gambiense) in vitro. Acta Trop, 1997; 68: 139-147.

Rollas S, Kucukguzel SG. Biological Activities of Hydrazone Derivatives. Molecules, 2007; 12(8): 1910-1939.

Santos PLP, Pinto GB, Takahashi JA, Silva LGF, Boaventura MAD. Biological screening of Annonaceous Brazilian medicinal plants using Artemia salina (Brine shrimp test). Phytomedicine, 2003; 10(2-3): 209-212.

Silverstein RM, Webster FX, Kiemle D. 2007. Spectrometric identification of organic compounds. De Boeck, $2^{\text {nd }}$ Edition.
Singh PK, Kumar DN. Spectral studies on cobalt(II), nickel(II) and copper(II) complexes of naphthaldehyde substituted aroylhydrazones. Spectrochimica Acta Part A, 2006; 64(4): 853-858.

Sleet RB, Brendel K. Improved methods for harvesting and counting synchronous populations of Artemia nauplii for use in developmental toxicology. Ecotoxicol Environ Safety, 1983; 7: 435-446.

Sreeja PB, Kurup MRP, Kishore A, Jasmin C. Spectral characterization, X-ray structure and biological investigations of copper(II) ternary complexes of 2-hydroxyacetophenone 4hydroxybenzoic acid hydrazone and heterocyclic bases. Polyhedron, 2004; 23: $575-581$

Tiuman TS, Ueda-Nakamura T, Garcia Cortez DA, Dias Filho BP, Morgado-Diaz JA, de Souza W, Nakamura CV. Antileishmanial activity of Parthenolide, a sesquiterpene lactone isolated from Tanacetum parthenium. Antimicrob Agents chemother., 2005; 492: 176-182.

Troeberg L, Chen X, Flaherty TM, Morty RE, Cheng M, Hua H, Springer C, McKerrow JH, Kenyon GL, Lonsdale-Eccles JD, Coetzer TH, Cohen FE. Chalcone, acyl hydrazide and related amides kill cultured Trypanosoma brucei brucei. Mol Med, 2000; 6(8): 660-9.

Vicini P, Incerti M, Doytchinova IA, La Colla P, Busonera B, Loddo R. Synthesis and antiproliferative activity of benzo[d]isothiazole hydrazones. Eur J Med Chem, 2006; 41(5): 624-32.

Wardakhan WW, Eid El-Sayed NN, Mohareb RM. Synthesis and anti-tumor evaluation of novel hydrazide and hydrazide-hydrazone derivatives. Acta Pharm, 2013; 63: 45-57.

Xia YL, Chuan-Dong F, Zhao BX, Zhao J, Shin DS, Miaom JY. Synthesis and structure-activity relationships of novel 1-arylmethyl-3-aryl$1 \mathrm{H}$ pyrazole-5-carbohydrazide hydrazine derivatives as potential agents against A549 lung cancer cells. Eur J Med Chem, 2008; 43: 2347-2353. doi: 10.1016/j.ejmech.2008.01.021.

Xu J, Cole DC, Chang CP, Ayyad R, Asselin M, Hao W, Gibbons J, Jelinsky SA, Saraf KA, Park K. Inhibition of the signal transducer and activator of transcription-3 (STAT3) signaling pathway by 4-oxo-1-phenyl-1,4-dihydroquinoline-3-carboxylic acid esters. J Med Chem, 2008; 51: 4115-4121. doi: 10.1021/jm701271y.

Zhang HZ, Drewe J, Tseng B, Kasibhatla S, Cai SX. Discovery and SAR of indole-2-carboxylic acid benzylidene-hydrazides as a new series of potent apoptosis inducers using a cell-based HTS assay. Bioorg Med Chem, 2004; 12: 3649-3655, doi: 10.1016/j.bmc.2004.04.017.

How to cite this article:

Bienvenu GLINMA, Fernand A. GBAGUIDI, Urbain C. KASSEHIN, Salomé D.S. KPOVIESSI, Alban HOUNGBEME, Horrhus D. HOUNGUE, Georges C. ACCROMBESSI and Jacques H. POUPAERT. Synthesis and trypanocidal activity of salicylhydrazones and $p$-tosylhydrazones of S-(+)-carvone and arylketones on African trypanosomiasis. J App Pharm Sci, 2015; 5 (06): 001-007. 